\title{
On Ethnic Identity: A Study of Share/Tsaragi Settlement in Nigeria (1830 -1967)
}

\author{
Abdulwahab Tijani \\ Department of General Studies, Ladoke Akintola University of Technology, \\ Ogbomoso, Nigeria \\ E-mail: immamtijani@yahoo.com
}

KEYWORDS Ethnic identity, culture, twin settlement, segregated residence

\begin{abstract}
The problems caused by the negative use of ethnic identities in modern multi-ethnic nations and its attendants violent ethnic crises has been focused by scholars. This has made researchers gloss over abundant cases in Africa especially in Nigeria where the use of ethnic identities in intergroup relations have not led to violence ethnic crisis. The objective of this paper is to understand the intergroup relations between the Nupe and Yoruba Ethnic groups in Share/Tsaragi twin settlements in Nigeria between 1830 - 1967. it has been observed that the intergroup relations between the two ethnic groups did not experience any recorded violent ethnic crises between $(1830-1967)$. This was due to the nature of pre-colonial intergroup relations between the two groups and the adoption of African approach to statesmanship.
\end{abstract}

\section{INTRODUCTION}

Inter-ethnic conflicts have been one of the most challenging problems of Nigeria and indeed many African Nations. These conflicts have led to various violent ethnic crises in Nigeria, such as the Zango Kataf crisis, the Sagamu/Kano riots, Ogoni crisis, Tiv/Jukun crisis etc. These violent crises have led to loss of life and properties and they have threatened the existence of Nigeria as a nation.

In attempt to find causes and proper solution to such crises, some writers believe that interethnic crises are inherently caused by the multiplicity of African modern Nations. For instance Layiwola writes that:

Nigeria is an apt, example where ethnic nationalities with differing religions and linguistic characteristics interact in conflicting situations under one pseudo-national constitution and laws. These tensions constantly generated are inimical to national integration and development. The conflict is further heightened by the co-existence of new as well as old social order, one jostling for ascendancy. (Dele, 1998).

Here Layiwola attributes the causes of ethnic conflicts in Nigeria to what Rotimi call "the existence of ethnic nationalities with differing religions and linguistic characteristics" (Rotimi, 1998).

It is based on this line of thought that Nkomi (1994) argues that the biggest obstacle to
Nigeria's integration is the diversity of culture, language and ethnic group.

Similarly, Odunuga opines that:

The political causes of conflict in many African countries have to do with the historical and structural handicaps which are the colonial legacy that has often been alluded to. The merging of ethnic groups into nations by colonial administrations did not erase ethnic divisions that existed before colonial rule (Segun, 1998).

This line of argument invariably assumes that the causes of inter-ethnic conflicts in Africa is inherently found in the multiplicity of ethnic groups, a culture and religion.

However, these diversities do not on their lead to inter-ethnic conflicts unless they are manipulated. This manipulation invariably leads to the stress of ethnic identity. Let us quickly observe that Nigeria has about 250 ethic and linguistic groups. Each of ethnic groups possessed their distinct group history political system, culture, religion and value systems. Some of these social actualities or differences were sometimes shared by neighbouring groups. "We can therefore say that each linguistic/ethnic group has its own identity" (Layiwola, 1998). There were the three major ethnic and linguistic groups of the Hausa, Yoruba and Ibo, occupying the north, south west and south east respectively. There were also important groups such as the Nupe, Ebirra, Igala, Jukun, Idoma, Gwari etc. found in the middle belt, Ijaw, Itseiri, Edo, Urohbo etc. found in the south-south. 
It is not enough to argue that the stress of ethnic identity alone could lead to inter-ethnic conflicts, rather we should go beyond this level and seek to understand how its stress have led to inter-ethnic crises in Nigeria.

Invariably, we see that the stress of ethnic identity and its exclusiveness does not occur in a vacuum. It is usually within the context of multiethnic rivalry and competition. Under this situation, ethnic identity is often manipulated by the dominant class to foster the advantage of their class within the context of the multi-ethnic society that is why some scholars view ethnicity in terms of hidden or disguised class interest. In this category are Nnoli and Chizea who view ethnicity as a disguise for class interest. Thus, ethnicity arises when primordial/sentimental or ethnic identity becomes a tool in the pursuance of group economic, political or social interests. It has thus been rightly argued that the effects of cultural identification (and hereby application the effect of ethnic identification) vary with the social and psychological situations of cultural groups. When a people are satisfied with its lifekeeping activities and feels secure, there are fewer tendencies to attack "outsider" (Eugene, 1998). But in the situation whereby the existence of a group is threatened physically, economically, politically or even when they perceived themselves as threatened, "their primordial sentiments heightened cultural differences so that cultural identification serves negative social function; the promotion of their group values, norms and patterns of thought at the expense of those other groups" (Eugene, 1998).

When primordial sentiment is employed negatively it can lead to the promotion of bigotry, arrogance and inter-ethnic conflicts (Eugene, 1998). Due to the fact that inter-ethnic conflicts have become serious problem in multi-ethnic nations such as Nigeria (John, 1990) and a most challenging barrier in the efforts of new nation towards national integration, many writers have given much attention to studies of causes of ethnic conflicts, with less attention on factor that foster the peaceful harmonious relationship between different ethnic groups:

The concern and interest in the history of one's settlement as a unit of social existence with its distinct occupations, mores, culture and atmosphere is superseded nowadays with this obsession which often used to pitch "indigenes" Vs. "strangers", "Natives" Vs. "settlers". (Garba, N.D.).
The study of community existence between the Yoruba and Nupe in Share/Tsaragi twin settlement is aimed at the historical reconstruction of how inter-ethnic conflicts were managed in the pre-colonial period in Nigeria. It is also aimed at understanding and factors and processes that assisted peaceful coexistence between the two groups. The history of intergroup relation in the Nigerian Landscape shows that people diversed ethnically and culturally had found common grounds to resolve their group differences when they were brought together by historical circumstances. Although the process was not always peaceful, but statesmanship often triumphed (Ikime, 1985). Our position in this paper is that the social actualities of ethnicity and ethnic identity do not necessarily lead to inter-ethnic conflict, rather what often leads to such conflicts is the (mis) use of ethnic identity in the struggle for economic advantages and political power.

Although, the stress of cultural identity has often led to crises between groups, in Share/ Tsaragi, the phenomenon of sustenance of ethnic identity did not lead to violent conflictual intergroup relations. It has been rightly argued that "not all identity is conflict generating" (Eugene, 1998). Rather, identity is the prerequisite of all kinds of positive group interaction in terms of exchange and solidarity, what is conflict generating is what a writer called "narcissitic identity" i.e. "the kind of identity whose affirmation, pursuit and defense form an integral part of the essence of nationalism (and of its lesser but not less murderous counterparts ethnicism and tribalism)" (Eugene, 1998).

Our study of Share/Tsaragi twin settlements of Yoruba and Nupe respectively have shown that although the segregation policy was adopted in the pattern of settlement and intergroup relations, the relationship has been peaceful and harmonious. Both groups maintain their ethnic identity as well as separate residential areas in the twin town. The twin towns, one of the Yoruba and the other of the Nupe respectively, is located along the northern fringes of Yorualand, close to Nupeland in the present Kwara State of Nigeria.

\section{HISTORY OF SETTLEMENT}

There are various versions of history of Share/Tsaragi settlement. One of the versions 
claimed that the Yoruba were the first to settle at the present site of Share in the year 1818 A.D. They were the Igbomina Yoruba group who came as hunters probably hunting for ivory. They left Ahun, their home place and first settled at Sakama, a place eastern part of Share. Another version claimed that the Yoruba left Oyo-Ile, (the capital of the Old Oyo empire) when it dispersed due to the Bariba expansionist wars in 1816. The Bariba army attacked Igboho which was then the capital of the Old Oyo empire. Oyo forces were defeated hence the civil population dispersed into different direction, some of them that went eastward were the ancestors of the Igbomina Yoruba who left Ahun and settled at Sakama. At Kpotofutayanci near Sakama were Nupe people who were mainly farmers. When the news of the Fulani Jihad wars got to them, the Yoruba people left Saama and emigrated to the present site of Share. One of them had located the site while hunting and had found the river Soose, thus he led the group to settle near the river (Ayo, L. 1999). Soon the Jihad displaced their Nupe counterparts at Sakama, they also left and settled amidst the Yoruba people at what later become Share. Share was walled initially with wood, thus the title of their king i.e. Olupako meaning 'the owner of the wood' was drived and later, the wall was made of mud. Later, due to frictions between the Nupe and the Yoruba, the Nupe were told to move to a segregated settlement near Opoto tree (Olive tree) thus drived the title of their chief Nda Opoto meaning the man leaving beside the Olive tree. Thus was later changed to Emir (Mohammed Alli : 1999). This segregated Nupe settlement was called Shagari i.e. small Share gaining a suffix meaning small in Nupe. However, in the course of rivalry over domination of the land and the river Soose, it was named Tsagari i.e. a small river in Nupe, apparently referring to river Soose (Mohammed Alli, 1990).

The Nupe version of the tradition claimed that the first settlers at Share were the Nupe, who left Atagara, settled at Sakama and later in the nineteenth century were driven by the Fulani Jihad to Share. At Share, the Yoruba people came and stayed with them, but because of cultural differences the Nupe people established a segregated settlement (Ndajoko, 1999). We observed that Bariba wars and the Fulani Jihad had the effect of bringing Yoruba and Nupe together as refuges in Share and Tsaragi and because of 'cultural conflicts' the two had to segregate their settlement thus Share/Tsaragi a twin town of Yoruba and Nupe was established. Each has its own traditional ruler. This segregation is an expression of the desire to have an ethnic identity i.e of Yoruba and Nupe respectively. It is also an attempt to control land resources.

Etuk rightly observes that:

...... among a people with whom attachment to the land is a very key sentiment, as Africans and certainly Nigerians, are, to have roots going back to even several generations means to be established. Perhaps it has something to do with being the original possessors of the land, or the first to arrive, and thus to possess this right of primogenitive (Etuk, 2002).

Therefore, we may argue that the maintenance of segregated settlement and ethnic identifies is primarily attached to the attempt to legitimize the control of land and river resources, rather than cultural conflicts. Fundamentally, there is nothing conflictual in the culture of the two groups. In fact, there are similarities in the culture of the two groups (Rotimi, 1996). Rather, the cultural argument is simply an ideological coat beneath which the territorial interest is hidden. Ajato captures this situation when he writes that:

The territory occupied by an ethnic group is perhaps the strongest national identity of the group. It is referred to as the land, country or territory of the ethnic group. Since it sustains the group's livelihood and represents the arena in which the ethnic group's existence may be observed, a major collective function of the group involves maintaining the group's territory integrity. The group becomes attached to its ethnic territory and defends it against intruders. (Madhi, 1994).

This struggle for territorial integrity and ethnic identity was well expressed through the establishment of separate settlements with separate political and administrative structure. Onipako as the political head of the Yoruba settlement while Nda Opoto, later Emir was the political head of the Tsaragi settlement (Garba, N.D.). This segregation policy evolved in the course of intergroup relations between the Yoruba and the Nupe people in Share/Tsaragi settlement. This arrangement was functional and harmonious. This is better expressed in Burton's argument that:

The political reality is that in many cases multi-ethnic societies become socially and 
political divided, and it is almost universally necessary to accord local autonomy in areas that are predominantly occupied by ethnic communities. It is dysfunctional in divided multiethnic societies to try to impose a central authority (John, 1990).

In the same vein as the issue of ethnic identities, the establishment of separate political autonomy is connected to the control of the hand resources. The political authorities are the superstructure that are based on the economic basis of the community, land and river resources, are primarily economic. Share/Tsaragi is located in the savannah region, with good arable land, the people are food crops farmers. Therefore, the segregation of Yoruba and Nupe settlements and the claim by each of the two groups of been the first settler is done in order to have control over land matters (territory) and legitimize such control.

Nevertheless, the relationship between the Yoruba and the Nupe people of Share/Tsaragi was of functional cooperation. John aptly describes this situation when he writes that:

Probably he only means of preserving cultural and concensus values, and the only means of integration (in the twin town) is through local autonomy in the short term. Separation promotes a sense of security from which there can be cooperative transactions between communities, leading finally to a higher degree of functional cooperation, if not integration (John, 1999).

In spite of the segregated residence of the Yoruba and Nupe in Share/Tsarag twin towns, the intergroup relationship between the two is harmonious rather than conflictual. There are no recorded cases of ethnic violence in spite of the stress of ethnic identity, one of Nupe, the other of Yoruba.

The reasons why the stress of ethnic identities in Share/Tsaragi by the Yoruba and Nupe ethnic groups did not lead to violent conflicts could be found in the per-colonial history of inter-group relations between the Nupe and Yoruba ethnic groups. The intergroup relations between the Yoruba and the Nupe ethnic group in the pre-colonial period span the economic, social, political and diplomatic fields. It however also experienced strains and hostilities which had resulted into warfares and shifts in political frontiers. The consequences of all these was that the groups had learnt to respect one another and live together in peace and harmony.
There is some evidence of trade relations between Yoruba and Nupe and other Northern Nigerian peoples before the nineteenth century. Clarperton in early $19^{\text {th }}$ century noticed in the market at Katunga (Old Oyo) that "trona or natron was brought from Bornu and sold in the Yorubaland, especially the coastal region where it was mixed with snuff and also used as medicine" (Mabogunje, 1971). The Lander brothers in 1832 gave more information about this trade. At Mowo coastal town near Badagry, they found trona (a vegetable alkali) and other commodities brought from the borders of the Saharan Desert through wandering Arabas. At jaguta area, a settlement near Igboho (Yorubaland), the Lander Brothers met "a party of Nouffice (Nupe) traders from Coniffo with assesses carrying trona for Gonja market" (Mobogunje, 1971). The assess were an important means of transportation. They witnessed caravans of merchants from Hausa, Borgu and other countries at Bum Bum near Kishi on their way to Gonja. At Kishi they noted that "great number of emigrants from Bargon, Nonffie, and Hausa, two or three Twancks from the border of the Great Desert (Mabogunje, 1971). Therefore, trade contact between Yorubaland and Nupe was largely through the trans-Saharan trade routes.

The Niger-Benue confluence peoples (where Nupe land is located) traded at important market centres such as Rabbah, Egga (lower down the Niger) (Funda or Odokobo) above the confluence rivers Niger and Benue, and at Ikri near Idah. At these market centres, Yoruba, Nupe, Fulani HaUSA, Bornu, Araba, Tuareg and other traders met to exchange commodities (Tamuno, 1996).

Commodities such as plain and dyed robes, cloth, saddles, bridles, sanders, beads, iron, raw indigo, armlets of copper, bowls, wooden spoons, calabashes spice nuts, pepper, sweet potatoes and onions were brought to the Egga market centre in Nupe land. The market centre was an important source of silk for the Yoruba country. The cocoons of wild moths were gathered and silk threads were spoon from their wrappings. Silk was also imported from North Africa through Kano to the Yoruba land.

At Rabbah centres, yams, rice, Indian corn, sweet potatoes, cows, sheep, goats, ivory, indigo ostriches, camels, leopard skins, bees wax and slave were sold. Rabbah market was more important than the market centre at Egga. However, Ikiri market centre was much more important, it is held for three days even ten days. 
Traders come from both sides of the River Niger and Benue. The ivory traders from Adamawa region, north-east of modern Nigeria, the trona merchants from Bornu, the Bonny and other slave dealers met at this market. These market centres continued to exist well into the $19^{\text {th }}$ century. Laired and Oldfield reported that more than 6,000 people attended the market and that about 11,000 slaves were sold every year and brought to the coast. Oyo (Yoruba Kingdom) probably purchased horses as well from these market centres (Ibid). These horses were very important in aiding the Oyo expansionist wars, especially towards the coast before the introduction of European gun and gun powder.

\section{SOCIAL RELATIONSHIP}

Social relationship between the Oyo-Yoruba people and their Nupe neighbours could be seen in terms of the exchange of religious and cultural influences. We can observe influences in religious activities such as the masquerades and the worshipping of Sango, Ifa and Sanponna deities. One of the common ways in which both Yoruba and Nupe represent the ancestral spirits is the masquerade called Egunnugun among the Yoruba, the Ndako Gboya or Igunnu among the Nupe. There are various myths and traditions of the origin of Egungun. Ile-Ife, Oyo and Nupeland were suggested by various scholars as places where it originated. However, (Kalilu, 1993) was able to prove that Egungun originated from Old Oyo and from there, it spread to other Yoruba groups as part of the influence of Old Oyo kingdom in the nineteenth centuryt. The spread also represented one of the effects of the collapse of the kingdom. He indicated that the masquerade called Oluyare origin is attributable to Ile-Ife. While Gugu masquerade found in NUpeland is traceable to the Old Oyo Kingdom, only Ndako Gboya is found to be of Nupe origin. This could be what Johnson refers to as "the introduction of the Egungun mysteries to the Yoruba by the Tapas (Nupes) on the hill Sandan at Kusu, where the secret was made known to Saha, the Kings head slave" (Samuel, J. 1966: 140). This was at a time when the Oyo refugees under their leader, Ofiran in Bariba land (Gbere) were moving to Oyo because they were suffering persecutions in the hands of the Baribas. They encampd at Kusi. They also adopted the worship of Ifa divinity as well as ancestor worshipping through the
Egngun. Johnson tells us that the first Egungun priest such as the Alapinni, Elefi, Olohan, Oloba, Aladafa and the Oloje were Nupe people who left Nupeland to join the Yorubas that emigrated from Bariba country. They instructed the Yoruba further in the Egungun worship.

If a appears to be the most important deity in Yorubaland. Each ruler, Oba or Baale, has an official Ifa priest called Babalawo that communicates with the gods on important state matters, its derivation is variously linked with either the Arabs, Nupe or Yorubaland itself. Johnson (Samuel, 1965) talks of the adoption of Ifa from Ota in the forest region of Yorbaland. The Oyo had rejected the Ifa worshipping when Aruigba-Ifa, the wife of Onigbogi, an Ota woman had introduced it to Alaafin Onigbogi. But after suffering persecution from the Bariba they believed that their suffering were due to their rejection of Ifa worshipping hence at Kishi, on their way to Oyo, they sent delegates to Ota to ask for initiation in the mysteries of Ifa worshipping. The Alade then came and initiated the Alafin and his people.

Sango worshipping was one of the main religions found in Oyo Kingdom. Sango was the fourth Alafin of the Kingdom and he was therefore a priest King. He becomes a deity after his death. He is the original thunder and solar divinity among the Yorubas. Sango is believed to often punish the offenders, such as those that engaged in lying, stealing and poisoning. He is believed to use lightening to punish offenders, such that any person struck by lightening is usually attended to by the Sango worshippers who prescribe rites to be performed and sacrifice to appease Sango.

In Nupeland, Sokogba is the thunder and solar divinity. It has many things in common with Sango. For example the grove of Sango in Oyo is called Koso while that of Sokogba is called Koso. This probably shows Oyo religious influences in Nupeland in the course of intergroup relations. This influence could have as come as a result of the relationship of Sango to the Nupe King Elempe. As said earlier, the Elempe was Sango's maternal grand-mother, and during his reign, Oyo's relationship with the Nupe King was cordial. Thus mean Sango became deified in Oyo after his demise, it was not improbable that the Nupe people would have shared in the veneration and worship of Sango as a dety (Obayemi, 1983).

An alternative view placed the possibility of 
Sango religious worship as one of the northern factors on Yoruba culture. Obayemi (1983) holds this view and he observes that Sango is believed to be the husband of 'Oya' among the Yoruba and the River Niger is referred to as 'Oyo' by the Yoruba. He argues that this points to the people of the Niger valley, up stream of the Nupe, namely, the Shanga, among who taking an oath involved disrobing and then taking a drink of water from the Niger. If the person had lied, it is believed that he would be struck by lightening (Obayemi, 1983).

The political, diplomatic and military relations between the NUpe and the Yoruba ethnic groups were mostly experienced during the series of wars that were fought between the Oyo (Yoruba) forces and the Jihadist (19 ${ }^{\text {th }}$ Century Fulani Jihad movement) in attempts to dislodge the Jihadists, but his army was defeated at Ogele, Oyo made another attempt by obtaining the help of the Nupe ruler at Rabbah across the Niger, again they were defeated in the 'Mugba-Mugba war in1824 1825.

In the last years of Oyo -Ile (the capital of Oyo Kingdom), Oyo and Bariba were brought into military alliance due to the common threat of the Jihadists in Ilorin. In 1834 A.D. Alafin Oluewu (the Oyo monarch) got military aid from Eleduwe, the Bariba ing also called Worukara Sarkin Nikki who personally came with a large army of Bariba archers to Oyo. This war is identified in Bariba's traditionl as having been led by the King of Nikki. Also, the king of Bussa, Kitoro, sent a contingent led by his nephew Gajere. These forces defeated Ilorin at Gbodo, in 1834 and at Otefan in 1833 but the allies were crushed in the final battle in 1855 - 1856. The Emir of Ilorin appealed to Gwandu for assistance and in 1837 the combined forces of Sokoto and Gwandu were sent to Ilorin. These were joined by the Nupe forces at Rabbah (Samuel, 1966). The final battle had devastating effects on Seku Kpera and the Kings of Wara and Kaima as well as Alafin Oluewu and his prince, the heir to the throne, all lost their lives, although Gajere of Bussa survived. Oyo-Ile the capital of Old Oyo Kingdom was sacked and abandoned for the second time, never again to be occupied. These political, military and diplomatic relations led to the conquest of parts of territories of one another and it also led to population movements. Such movements occasioned the establishment of Share/Tsaragi. The circumstances of the establishment of this twin settlement made it easy for the Nupe and Yoruba people to adopt harmonious intergroup relation having fled from war fronts.

\section{CONCLUSION}

By and large, the history of Share/Tsaragi has shown that intergroup relations between the Nupe and Yoruba people in the twin settlement are primarily influenced by the desire to control land resources. This gave rise to the variation in the oral history of the settlement; the adoption of ethnic segregated residence, seeking ethnic identity and their political superstructure. The inter-ethnic relations did not lead to the employment of African approach to statesmanship and the nature of the pre-colonial inter-group relations between the Nupe and Yoruba ethnic groups.

\section{REFERENCES}

Chief N. 1999. Personal Interview

Cohen, A 1969. Customs and Politics in Urban Africa. London: R. \& K. Paul

Dele Layiwola 1998. "Identity and the Quest for Nationhood in Nigeria", in O. Olusegun, (ed). Ibadan Journal of Humanistic Studies, 8(2): 74 90.

Etuk U. 2002. Relgion and Cultural Identity. Ibadan: Hope Publications.

Eugene, W. (Ed.) 1998. The Handbook of Ethnic Coexistence. New York: Abraham Fond.

Garba A. (Ed) (N.D.) Cities of Savannah. Lagos: Nigeria Magazine Cultural Division. F.M.I.

Ikime, O.A. 1985. Intergroup relation in an evolving nation." Paper presented at a Conference of the Historical Society of Nigeria, Ibadan, Johnmof.

John, B. 1990. Conflict: Resolution and Prevention. New Yor: Macmillian Macmillian

Kalilu, R.O.R. 1993. "Costumes and Origin of Egungun.” African Studies, $52: 1$.

Madhi, A., A. K. George and Y. Mahmood (Eds.) 1994. Nigeria: The State of the Nation and the Way Forward. Kaduna: Arewa House.

Mallam Mohammed A. 1999. Personal Interview Share

Nicom, S. 1994. "The Social Basis for National Integration", (Pp. 434 - 443), in A. Mahdi, A. K. George and Y. Mahmond (eds), Nigeria: The State of the Nation and the Way Forward. Kaduna: Arewa House.

Obayemi, A 1983: "History, Culture, Yoruba and Northern Factors", (P. 83), in G. O. Olusanya (ed). Studies in Yoruba History and Culture. Ibadan: I.U.P.

Rotimi T.S. 1996. Ethnic Minority Conflicts and Governance in Nigeria. Ibadan: Spectrum Books:

Tijani, A. 1999. Ethnic Conflicts in Nigeria: A Case Study of Sagamu/Kano Riots ELA. Journal of African Studies, 5 \& 6: $74-90$ 
Tijani, A. 2003. Sabo Communities in Yorubaland, Nigeria (1916-1917). Ph. D Thesis (Unpublished), Department of History, Unilorin: University of Ilorin.

Samuel, J. 1996. The History of the Yorubas, Lagos: CMS.

Segun Odunuga 1998. "Managind African Conflicts: The
Political Economic and Social Dimensions." Ibadan Journal of Humanistic Studies, 8: 65 - 70 Tamuno, T.N. 1986. "Peoples of the Niger-Benue Confluence", (P. 215) in J J. F. Ajayi and Evans Ians (eds.), A Thousand Years of West African History. Ibadan, I.U.P. 